\title{
PENINGKATAN PERFORMANSI APLIKASI PEMBEDA SUARA LAKI-LAKI DAN PEREMPUAN BERDASARKAN FREKUENSI DENGAN MENGGUNAKAN METODE FUZZY LOGIC
}

\author{
Andi Sri Irtawaty ${ }^{1}$, Maria Ulfah ${ }^{2}$, Eka Reina Elfira Tamzil ${ }^{3}$ \\ Jurusan Teknik Elektro Politeknik Negeri Balikpapan ${ }^{123}$ \\ Email Korespondensi : andi.sri@poltekba.ac.id
}

\begin{abstract}
Along with the development of technology, the technique of identification of human voices based on sex is very necessary for some parties, especially in the field of education. The main parameter in distinguishing male and female voices is the frequency of the same one-word pronunciation sample with the same duration and pressure. To solve this problem, have been designed a matlab application based on male and female voice differentiator and the results will be improved by the fuzzy logic method. Based on the application testing, of the 20 human voice samples tested, there was 1 sound sample that was difficult to identify, so the accuracy level was only 95\%. However, by using the fuzzy logic method, 1 sound sample can be classified in the form of female voices, so the performance of male and female voice differentiator applications increases to 100\%. The final results of this study obtained a range of male voice signal frequencies $81.93 \mathrm{~Hz}$ to $233.3 \mathrm{~Hz}$ while the frequency range of female voice signals $316.9 \mathrm{~Hz}$ to $575.5 \mathrm{~Hz}$.
\end{abstract}

Keywords : Voice, frequency, fuzzy logic, duration and pressure

\section{INTISARI}

Seiring perkembangan teknologi, teknik identifikasi suara manusia berdasarkan jenis kelamin sangat diperlukan untuk oleh beberapa pihak terutama dibidang pendidikan. Parameter utama dalam membedakan suara laki-laki dan perempuan adalah frekuensi dari sampel pengucapan satu kata yang sama dengan durasi waktu dan tekanan yang sama. Untuk memudahkan hal tersebut, maka dirancanglah sebuah aplikasi pembeda suara laki-laki dan perempuan berbasis matlab dan hasilnya akan ditingkatkan performansinya dengan metode fuzzy logic. Berdasarkan pengujian aplikasi tersebut, dari 20 sampel suara manusia yang diujikan, ada 1 sample suara yang sulit teridentifikasi, sehingga tingkat keakuratannya hanya 95\%. Namun dengan menggunakan metode fuzzy logic, 1 sample suara tersebut dapat diklasifikasikan berupa jenis suara perempuan, sehingga performansi aplikasi pembeda suara laki-laki dan perempuan meningkat menjadi $100 \%$. Hasil akhir penelitian ini diperoleh range frekuensi sinyal suara laki-laki $81.93 \mathrm{~Hz}$ sampai $233.3 \mathrm{~Hz}$ sedangkan range frekuensi sinyal suara perempuan $316.9 \mathrm{~Hz}$ sampai $575.5 \mathrm{~Hz}$

Kata kunci: Suara, frekuensi, fuzzy logic, waktu, tekanan

\section{PENDAHULUAN}

Berdasarkan jenis kelamin, suara manusia terbagi atas 2 jenis yaitu suara laki-laki dan suara perempuan. Dari penelitan sebelumnya dijelaskan bahwa proses pengklasifikasian suara manusia diperoleh berdasarkan parameter durasi waktu pengucapan, amplitudo dan daya sinyal suara [1]. Namun perlu diketahui bahwa jenis suara pada manusia selain memiliki ketentuan ambitus nada, juga memiliki ketentuan jangkauan frekuensi yang berbeda-beda sesuai dengan ketentuan ambitusnya [2]. Dalam penelitian ini, akan dirancang sebuah aplikasi pembeda suara laki-laki dan suara perempuan dengan menggunakan parameter frekuensi. Proses pengambilan sampel suara dilakukan secara live dan otomatis hasilnya akan ditampilkan langsung pada program aplikasi tersebut (laki-laki atau perempuan). Perbedaan penelitian ini dari penelitian sebelumnya, yaitu pada penelitian sebelumnya pengambilan sampel suara dilakukan menggunakan handphone kemudian dengan menggunakan aplikasi format factory, sample suara tadi dikonversikan menjadi format wav, lalu proses selanjutnya yaitu menampilkan bentuk gelombangnya menggunakan program matlab. Namun pada penelitian ini, semua proses 
Jurnal ECOTIPE, Volume 7 No 1, April 2020, Hal. 1-6

p-ISSN 2355-5068, e-ISSN 2622-4852

Akreditasi Kemenristekdikti (SINTA 4), SK. No.10/E/KPT/2019

DOI: 10.33019/ecotipe. v7i1.1636

pengambilan sample suara hingga menampilkan hasilnya dilakukan secara otomatis.

Berdasarkan penelitian sebelumnya dijelaskan bahwa parameter utama dalam mengklasifikasikan suara manusia adalah frekuensi fundamental, yaitu frekuensi asli suara manusia tanpa resonansi [3]. Sedangkan apabila suara dasar tersebut bercampur dengan suara yang ada di sekelilingnya atau beresonasi, maka frekuensi yang diperoleh disebut frekuensi harmonik [4].

\section{LANDASAN TEORI}

Dalam aplikasi pembeda suara laki-laki dan perempuan yang dirancang ini memiliki kemampuan yaitu mampu menampilkan karakteristik bentuk asli gelombang / sinyal suara manusia dan dilengkapi filter untuk menapis noise yang bercampur pada suara aslinya. Parameter utama dari inputnya adalah frekuensi. Karena pengambilan sampel suara dilakukan secara live, maka bentuk sinyal suara yang ditampilkan mengandung frekuensi harmonic yang akan difilter terlebih dahulu agar diperoleh frekuensi fundamentalnya dari setiap sampel suara yang diujikan.

Untuk mendapatkan hasil pengujian yang maksimal, digunakan metode fuzzy logic yaitu sebuah metode pengklasifikasian yang tepat untuk memetakan suatu ruang input ke dalam suatu ruang output, serta mempunyai derajat keanggotaan dan derajat kebenaran. Logika Fuzzy memungkinkan nilai keanggotaan antara 0 dan 1 serta ada nilai diantara keduanya (nilai samar). Kelebihan metode fuzzy logic yaitu mudah dimengeri, fleksibel dan memiliki toleransi terhadap data yang kurang tepat [5].

Pembuatan aplikasi pembeda suara laki-laki dan perempuan menggunakan software matlab. Parameter input nya adalah suara manusia. Ciri yang akan diidentifikasi adalah frekuensi dari setiap sampel suara dengan satu kata pengucapan yang sama, yaitu "Poltekba". Untuk menghasilkan data akurat, maka setiap sampel suara mengulangi pengucapan tersebut, masing-masing 10 kali, sehingga total sampel yang akan diujikan dengan metode fuzzy logic sebanyak 200 sampel.

\section{METODE PENELITIAN}

Urutan detail metode penelitian meliputi studi literature, proses perancangan aplikasi, pengujian aplikasi, analisa hasil dan kesimpulan.

Secara detail akan diuraikan sebagai berikut :

1. Studi literature yang dilakukan bertujuan untuk menyempurnakan penelitian sebelumnya, dimana pengambilan sampel suara terpisah dengan perangkat analisa sinyalnya, maka akan disempurnakan menjadi satu aplikasi lengkap mulai dari pengambilan suara hingga proses analisa hasilnya dijadikan satu perangkat.

2. Perancangan aplikasi pembeda suara laki-laki dengan suara perempuan ini menggunakan software matlab dalam tampilan guinya. Kekurangan dari penelitian sebelumnya dapat terselesaikan dalam aplikasi ini, yaitu pengambilan sampel suara dilakukan secara live dan otomatis tampilan bentuk gelombang akan langsung ditampilkan oleh GUI matlab beserta hasil klasifikasinya (gambar 1).

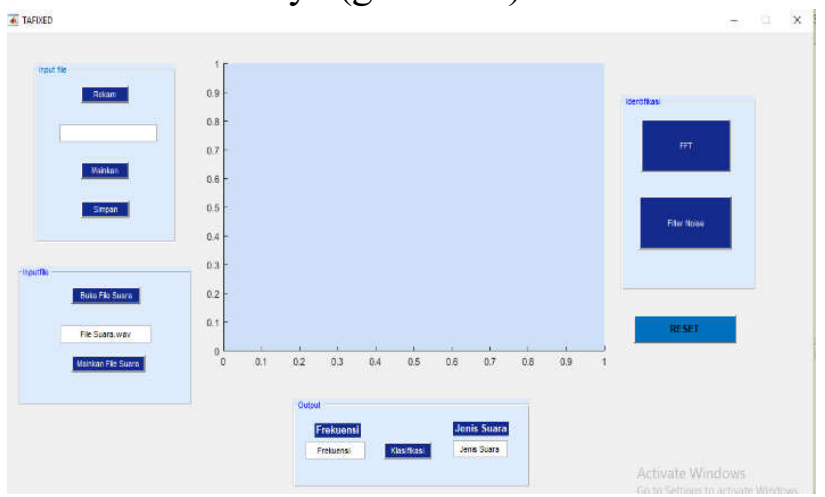

Gambar 1 Tampilan GUI matlab

3. Pengujian aplikasi GUI matlab, dengan penginputan sampel suara sebanyak 20 sampel, dilanjutkan dengan perulangan 10 kali untuk masing-masing sampel suara dengan pengucapan kata "Poltekba" pada tekanan normal dalam durasi 2 detik. Hasilnya secara otomatis bentuk gelombang setiap sampel suara beserta klasifikasinya akan ditampilkan pada GUI matlab seperti yang disajikan pada gambar 2 . 
Jurnal ECOTIPE, Volume 7 No 1, April 2020, Hal. 1-6

p-ISSN 2355-5068, e-ISSN 2622-4852

Akreditasi Kemenristekdikti (SINTA 4), SK. No.10/E/KPT/2019

DOI: 10.33019/ecotipe. v7i1.1636

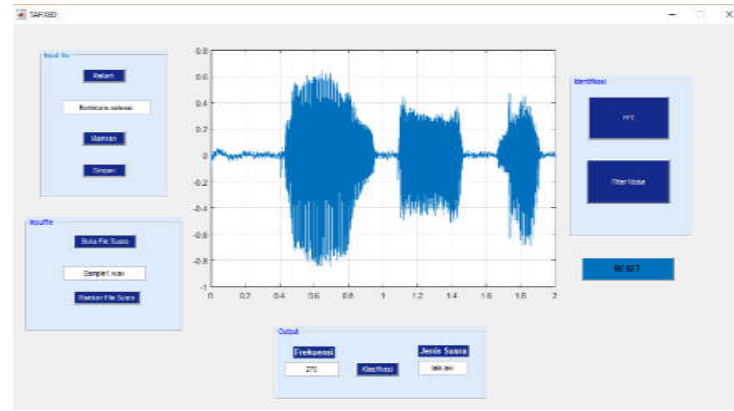

Gambar 2 Tampilan sinyal sampel suara

4. Analisa hasil. Pada tahapan ini, seluruh bentuk gelombang dari 20 sampel suara, akan dianalisa keakuratan klasifikasinya dengan metode fuzzy logic (gambar 3).

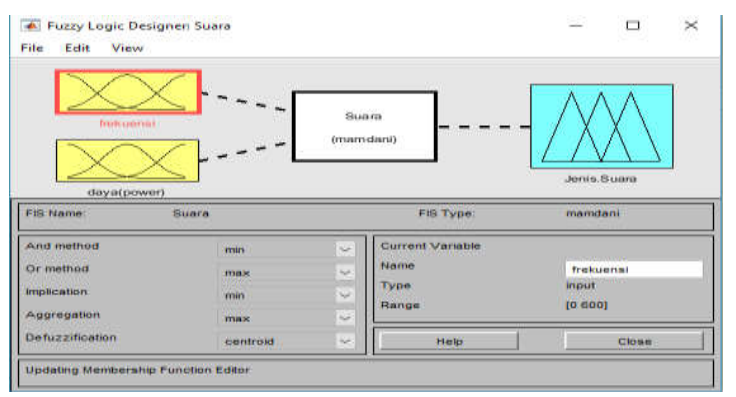

Gambar 3. Tampilan fuzzy logic

Berikut ini menyajikan diagram alir (flowchart) terkait langkah-langkah analisa dengan metode fuzzy logic (gambar 4).

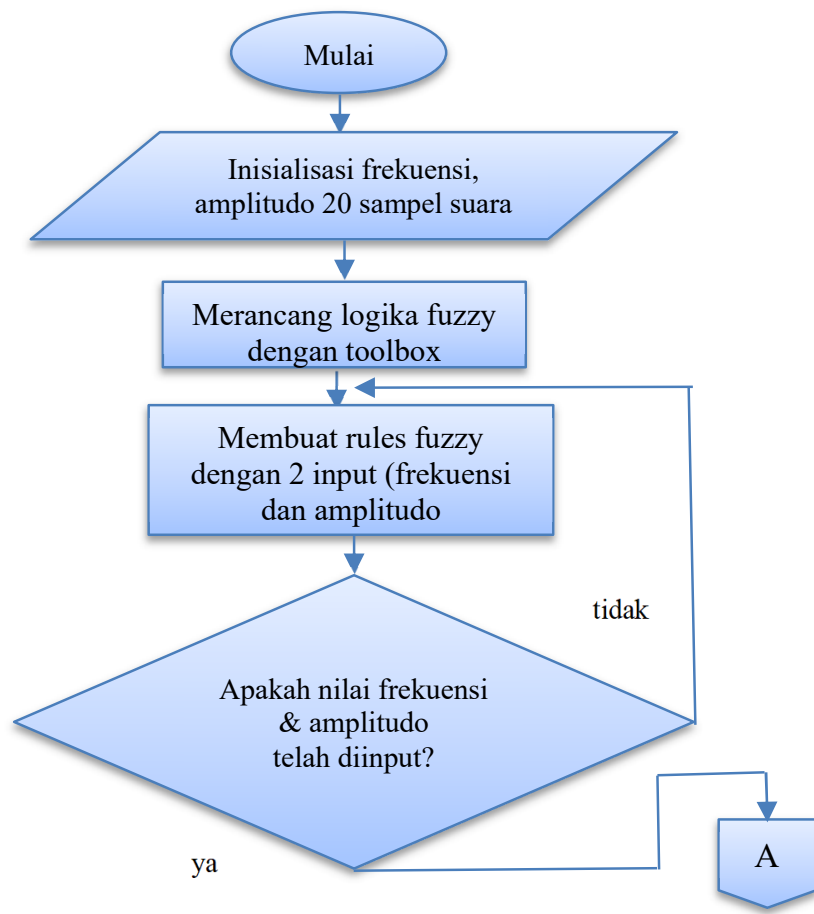

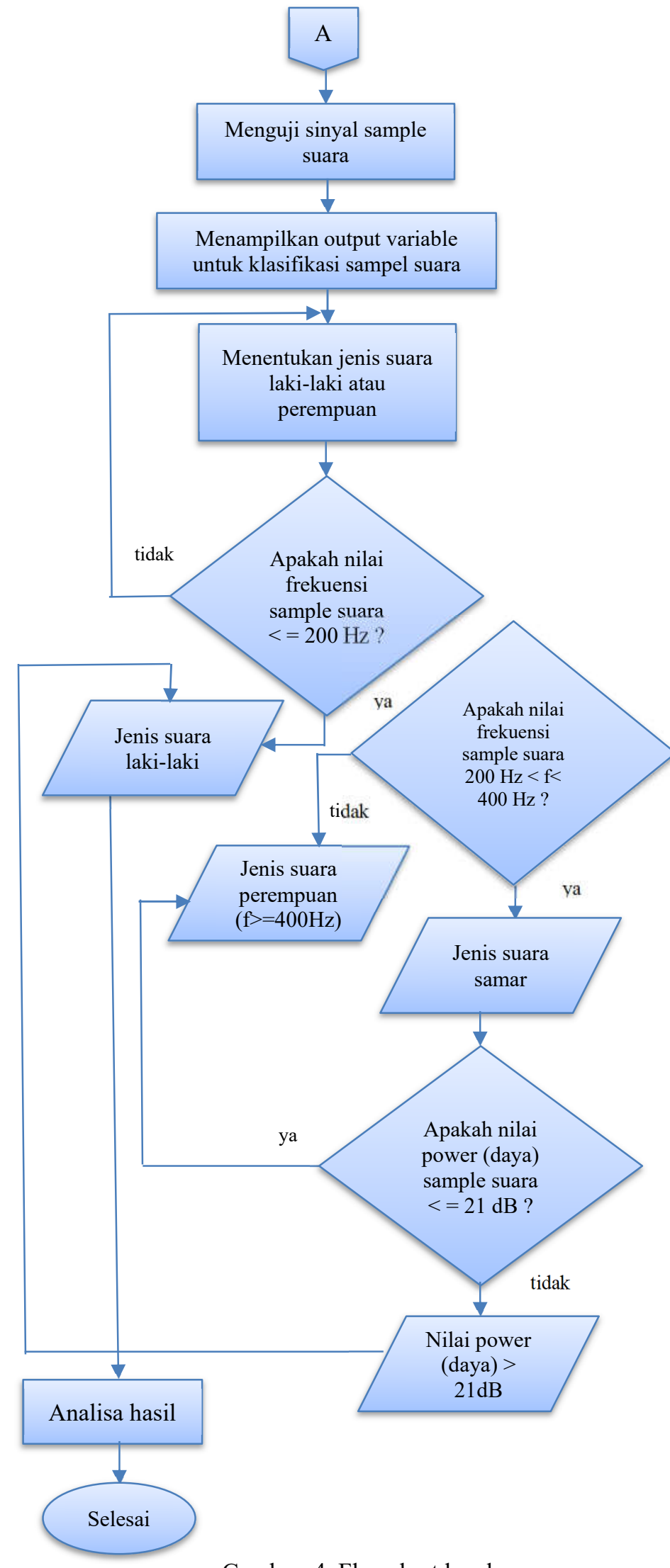

Gambar 4. Flowchart lengkap 
Jurnal ECOTIPE, Volume 7 No 1, April 2020, Hal. 1-6

p-ISSN 2355-5068, e-ISSN 2622-4852

Akreditasi Kemenristekdikti (SINTA 4), SK. No.10/E/KPT/2019

DOI: 10.33019/ecotipe. v7i1.1636

5. Kesimpulan. merupakan tahapan akhir yang akan merumuskan hasil analisa yang telah dilakukan terhadap 20 sampel suara, sekaligus menentukan performansi keakuratan dan aplikasi GUI matlab tersebut.

\section{HASIL PENELITIAN DAN PEMBAHASAN}

3.1 Analisa Hasil dari Aplikasi Pembeda Suara laki-laki dan perempuan

Untuk menganalisa hasil keluaran akhir dari aplikasi pembeda suara laki-laki dan perempuan, digunakan metode fuzzy logic. Gambar 5 berikut menyajikan tampilan toolbox fuzzy logic untuk parameter input 1 (frekuensi).

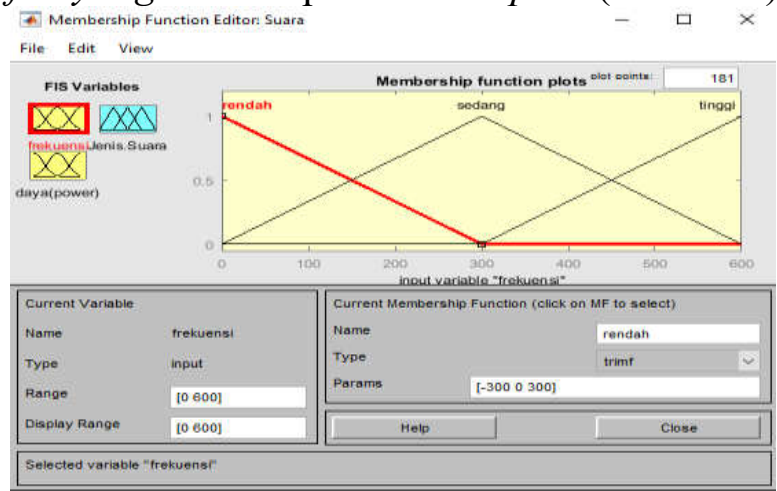

Gambar 5 Parameter input1 (frekuensi)

Gambar 6 menyajikan parameter input 2 yaitu daya (power).

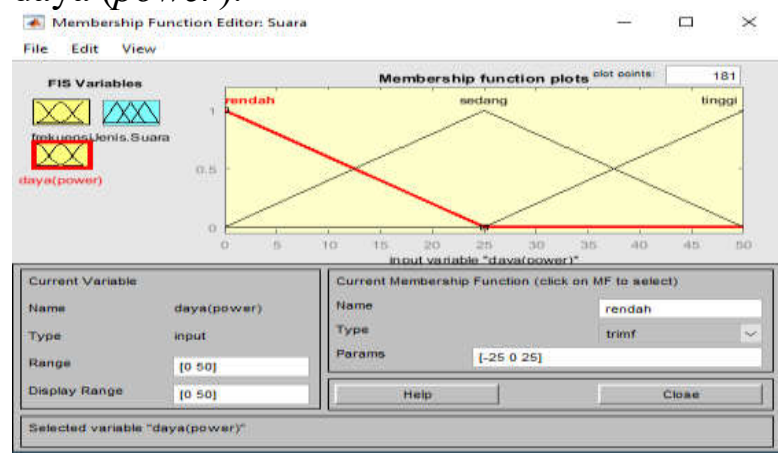

Gambar 6 Parameter input 2 (daya / power)

Dalam menentukan hasil output (jenis suara laki-laki atau suara perempuan), maka perlu dirancang rules fuzzy logic seperti disajikan pada gambar 7.

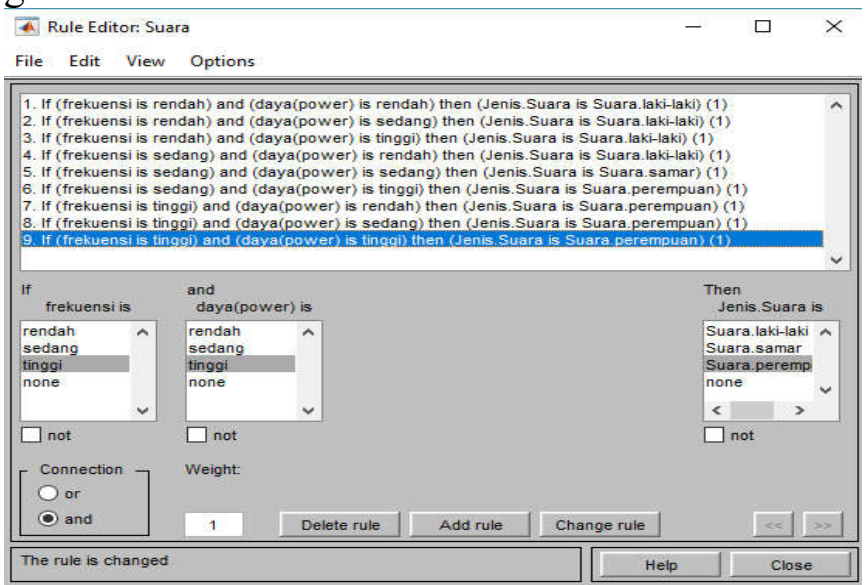

Gambar 7 Rules Fuzzy Logic

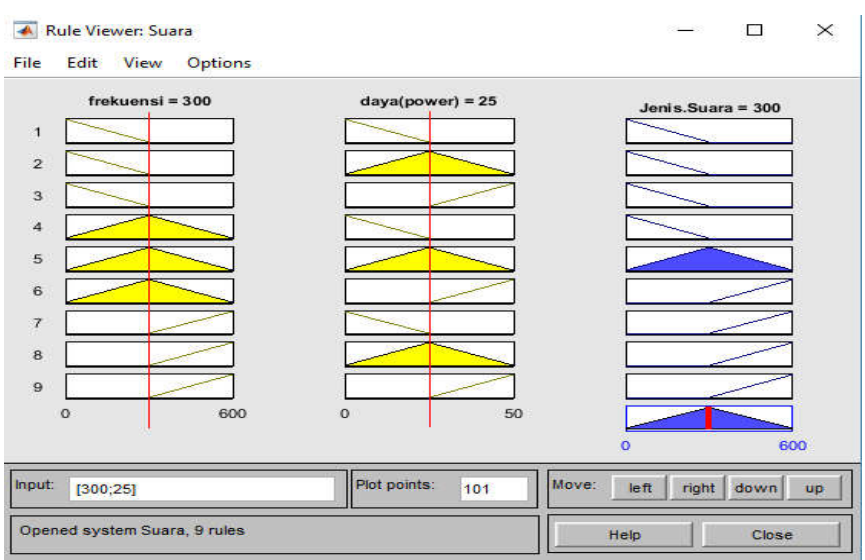

Gambar 8 Rules viewer suara

Pada gambar 8 terlihat pada rules ke-5 yaitu saat frekuensi $=300 \mathrm{~Hz}$ dan daya $=25 \mathrm{~dB}$, segitiga hasil klasifikasi suara berada pada kondisi samar (segitiga biru). Demikian pula saat frekuensi $=600 \mathrm{~Hz}$ dan daya $=50 \mathrm{~Hz}$, merupakan data yang sulit teridentifikasi.

Dari 20 sampel suara uji, berhasil diklasifikasikan yaitu terdapat 2 sample suara perempuan, 17 sample suara laki-laki dan 1 sample suara yang sulit teridentifikasi (frekuensi $=575.5 \mathrm{~Hz}$ dan daya $=37.34 \mathrm{~dB}$ ). Jika mengacu pada rule ke-9, yaitu frekuensi tinggi dan daya tinggi, maka hasil klasifikasi suara adalah perempuan. Tabel 1 berikut menyajikan hasil klasifikasi 20 sampel suara menggunakan metode fuzzy logic. 
Jurnal ECOTIPE, Volume 7 No 1, April 2020, Hal. 1-6

p-ISSN 2355-5068, e-ISSN 2622-4852

Akreditasi Kemenristekdikti (SINTA 4), SK. No.10/E/KPT/2019

DOI: 10.33019/ecotipe. v7i1.1636

Tabel 1 Perbandingan hasil klasifikasi sample suara dengan metode FFT dan metode Fuzzy Logic.

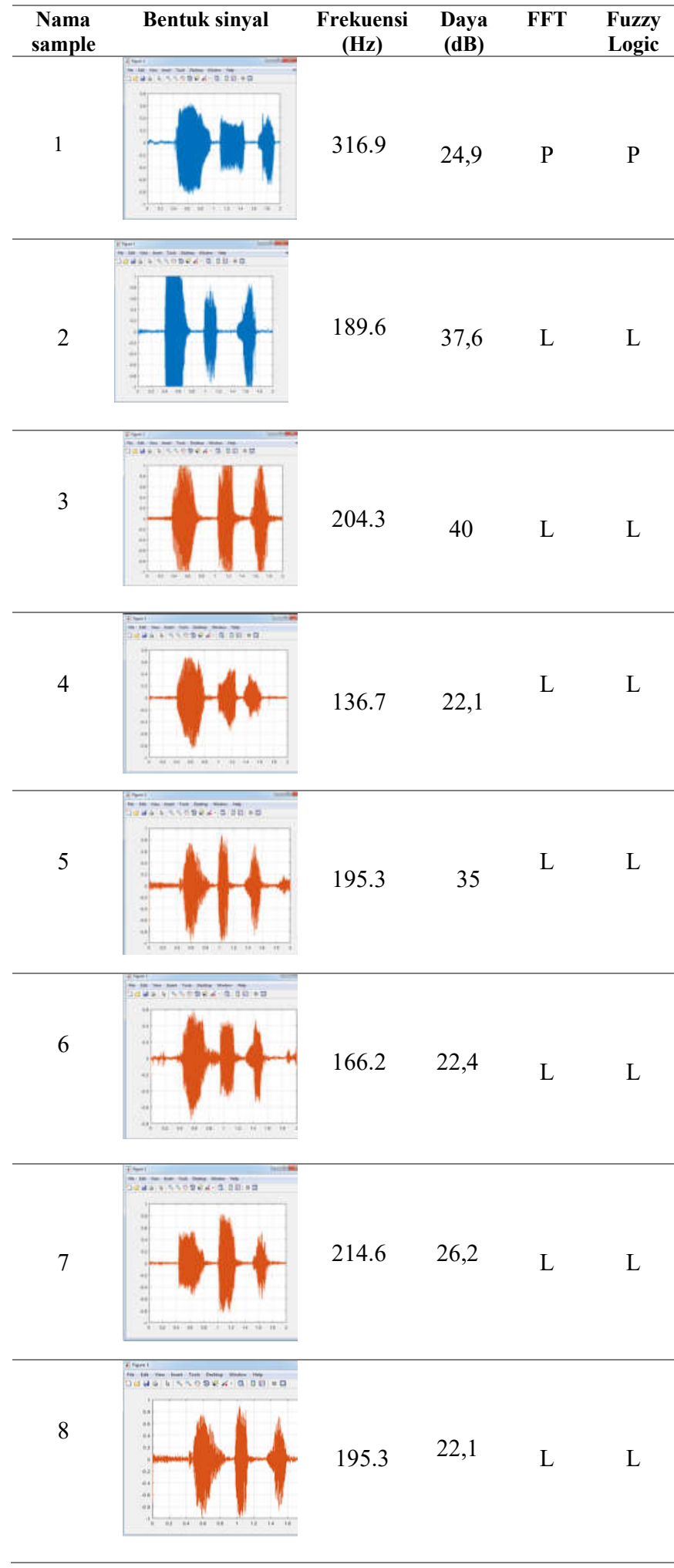

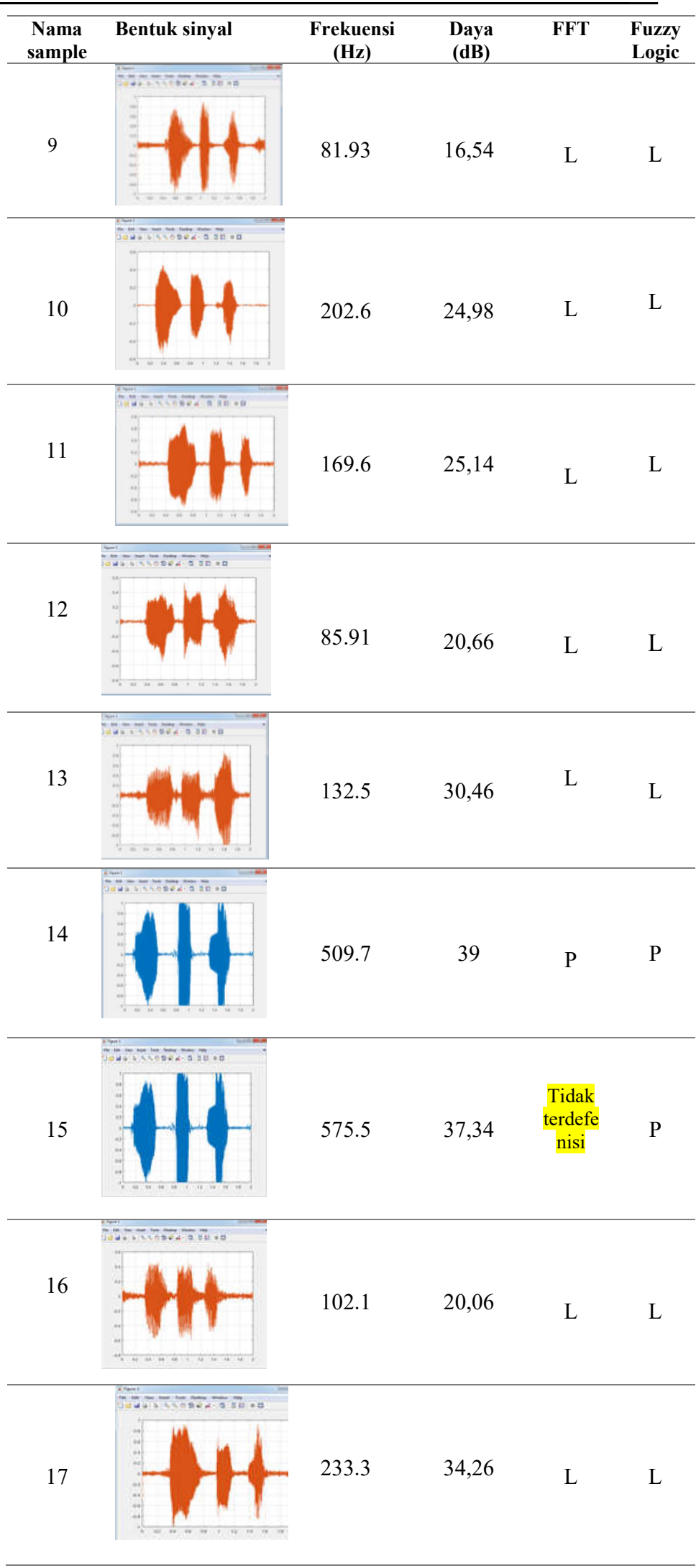


Jurnal ECOTIPE, Volume 7 No 1, April 2020, Hal. 1-6

p-ISSN 2355-5068, e-ISSN 2622-4852

Akreditasi Kemenristekdikti (SINTA 4), SK. No.10/E/KPT/2019

DOI: 10.33019/ecotipe. v7i1.1636

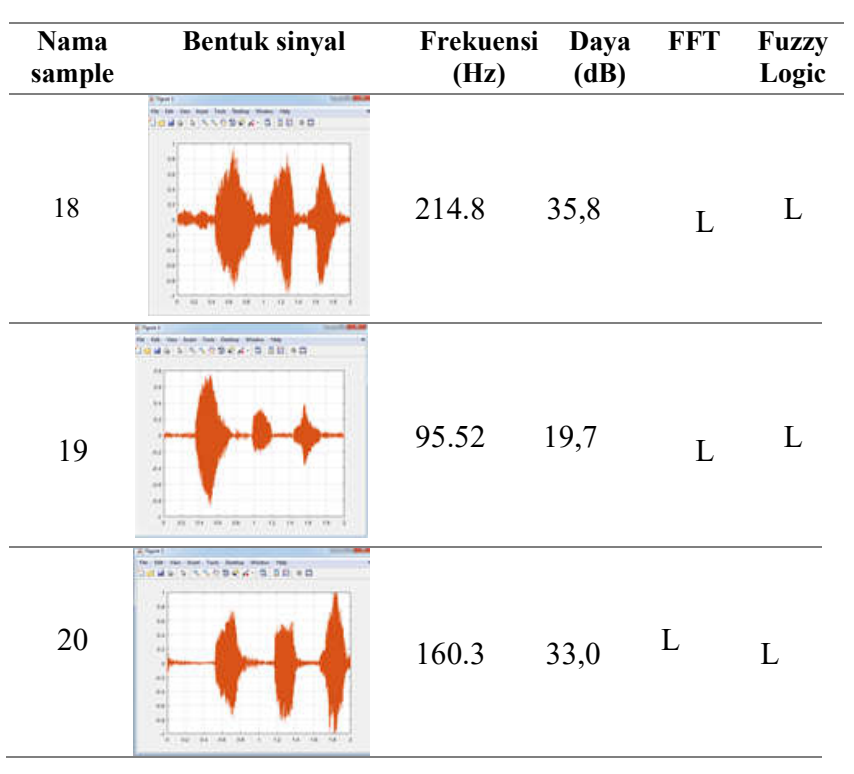

Perhatikan data ke-15, pada metode FFT tidak mampu mengklasifikasikan jenis suara lakilaki atau perempuan. Namun dengan metode fuzzy logic, sesuai aturan rule ke-9, maka sample suara ke-15 termasuk suara perempuan.

\section{KESIMPULAN}

Aplikasi pembeda suara laki-laki dan suara perempuan dengan menggunakan software matlab dianggap memiliki keakuratan sekitar 95\%. Dari 20 sample suara yang diujikan, terdapat 1 sample yang sulit teridentifikasikan. Namun dengan pengujian melalui metode fuzzy logic, maka 1 sample data tersebut dapat diklasifikasikan yaitu jenis suara perempuan. Berarti aplikasi pembeda suara laki-laki dan perempuan dengan metode FFT hanya memiliki keakuratan $95 \%$, namun dengan dikombinasikan dengan metode fuzzy logic maka menghasilkan klasifikasi dengan tingkat keakuratan $100 \%$.

\section{DAFTAR PUSTAKA}

[1] A. S. Irtawaty, "Implementasi Metode Fast Fourier Transform (FFT) Dalam Mengklasifikasikan Suara Pria dan Wanita di Laboratorium Jurusan," Jurnal Terpadu Teknologi, vol. 7, no. 2, Oktober 2019.

[2] B. Susanto, "Identifikasi Suara Pria dan Wanita berdasarkan Frekuensi Suara," Universitas Kristen Duta Wacana, 2011.

[3] A. Ahmadiyah, "Sistem Rekomendasi Lagu Berdasarkan Jenis Suara Penyanyi Pada Aplikasi Karaoke.," Jurnal Ilmiah Teknologi Informasi, vol. 15, no. 2, pp. 248-255, 2017.

[4] W. Rahim, "Analisis Spektrum Suara Manusia Berdasarkan Jenis Kelamin (Gender) Dan Kelompok Umur Menggunakan Komputer.," Jurnal IOM FMIPA, vol. 2, no. 1, 2015.

[5] T. Sejati, "Klasifikasi Suara Burung Lovebird Dengan Algoritma Fuzzy Logic. e-Proceeding of Engineering," e-Proceeding of Engineering, vol. 2, no. 2, p. 3171, 2015. 